\title{
Pijat Marmet Sebagai Solusi Produksi Asi Ibu Menyusui Di Kecamatan Sikur Kabupaten Lombok Timur
}

\author{
Baiq Maryam, Sastrawan, Menap \\ Program Studi Magister Administrasi dan Kebijakan Kesehatan \\ Universitas Qamarul Huda Badaruddin \\ Email: Mer311980@gmail.com
}

\begin{abstract}
Abstrak. Latar Belakang : Pemberian ASI eksklusif merupakan salah satu program yang dicanangkan oleh pemerintah untuk mengurangi kematian bayi. Cakupan ASI Ekslusif di NTB mencapai angka $82 \%$ berarti masih ada sekitar $18 \%$ yang belum ASI ekslusif, banyak faktor yang mempengaruhi pemberian ASI diantaranya adalah masalah produksi ASI yang tidak lancar, sehingga perlunya pemberian terapi yang tepat dalam mengatasi masalah produksi ASI. Desain penelitian dalam penelitian ini adalah one group pretest postets design .Penelitian ini jumlah sampel dalam penelitian ini sebanyak 17 responden yang diambil dengan teknik total sampling. Dan tujuan penelitian ini adalah melihat pengaruh dari pijat marmet terhadap produksi ASI ibu menyusui di Kecamatan Sikur Kabupaten Lombok Timur. Berdasarkan hasil uji statistik, dapat diperoleh nilai rata-rata produksi ASI sebelum intervensi sebanyak 603,41 dan mengalami peningkatan setelah diberikan intervensi dengan pijat marmet menjadi 766,11. Nilai rata-rata tingkat produksi ASI menunjukan adanya peningkatan jumlah produksi ASI setelah diberikan terapi pijat marmet sebesar 162,70 dengan p value 0,000 lebih kecil dari $\alpha$ $=0,05$. Kesimpulan penelitian ini adalah adanya pengaruh yang signifikan pemberian terapi pijat marmet terhadap peningkatan produksi ASI ibu di Kecamatan Sikur Kabupaten Lombok Timur.
\end{abstract}

Keyword: Pijat Marmet, ASI (air susu ibu)

\section{PENDAHULUAN}

Air susu ibu merupakan suatu cairan kompleks dengan sejumlah besar protein, sel, dan komponen lainnya. Pengetahuan tentang dampak menyusui pada bayi terus meningkat, termasuk dampak langsung dan tidak langsung pada sistem imun. Pengaruh imunologis berhubungan dengan kenyataan bahwa ASI kaya dengan berbagai faktor aktif khususnya antibodi(Aldy, et al., 2009).

WHO telah mengeluarkan salah satu standar emas pemberian makan melalui Global Strategy Infant Young Child Feeding (IYCF) pada tahun 2003 untuk terus menyusui selama dua tahun pertama berdasarkan fakta bahwa ASI terus menjadi sumber nutrisi utama dan selama tahun kedua menyusui, ASI masih memiliki zat pelindung (kekebalan) yang dapat mengurangi risiko penyakit infeksi pada balita dan meningkatkan kemampuan kognitif dan produktivitas di usia dewasa(Ervina, Yustina, \& Sudaryati, 2019).

Banyak Faktor yang mempengaruhi produksi ASI berasal dari internal dan eksternal. Faktor internal meliputi kondisi fisik, psikologis, pengetahuan ibu dan faktor fisik bayi sedangkan faktor eksternal diantaranya inisiasi menyusui dini (IMD) dan frekuensi menyusui yang akan mempengaruhi produksi hormon dalam tubuh Ibu ( Kadir, 2014).
Pemberian ASI eksklusif merupakan salah satu program yang dicanangkan oleh pemerintah untuk mengurangi kematian bayi. Penelitian epidemiologi menyatakan bahwa ASI dapat melindungi bayi dan anak dari penyakit infeksi, seperti diare, otitis media dan infeksi saluran pernafasan akut bagian bawah. Kolostrum ASI mengandung zat kekebalan 10-17 kali lebih banyak dari susu matang (matur)(Andayani, Emilia, \& Ismail, 2017).

Berdasarkan Data Dinas Kesehatan Provinsi NTB (2019) cakupan ASI Ekslusif di NTB mencapai angka $82 \%$ berarti masih ada sekitar $18 \%$ yang belum ASI ekslusif, banyak faktor yang mempengaruhi pemberian ASI diantaranya adalah masalah produksi ASI yang tidak lancar.

Masalah dari produksi ASI, selain produksi ASI bisa di tingkatkan dengan jalan terus menyusui setiap kali bayi menginginkan, ada beberapa hal yang bisa menghambat produksi ASI adalah feedback inhibitor yaitu suatu faktor lokal, yakni bila saluran ASI penuh, maka mengirim impuls untuk mengurangi produksi. Stres/rasa sakit maka akan menghambat atau inhibisi pengeluaran oksitosin. Misalnya pada saat sinus laktiferus penuh/payudara sudah bengkak (Astuti, Dewi, Judistiani, Rahmiati, \& Susanti, 2015)Soetjiningsih, 2012). 
Evariny (2008) Inisisasi menyusui dini (IMD) di jam-jam pertama kelahiran jika tidak dapat dilakukan oleh ibu akan menyebabkan proses menyusui tertunda, maka alternatif yang dapat dilakukan adalah memerah atau memompa ASI selama 10-20 menit hingga bayi dapat menyusui. Jika teknik ini dilakukan dengan efektif dan tepat, maka seharusnya tidak akan terjadi masalah dalam produksi ASI atau cara mengeluarkan ASI. Dan cocok untuk mengatasi masalah terhambatnya ASI pada saat masa bencana seperti saat ini, seperti yang pernah terjadi pada saat gempa Lombok ada ada sekitar 4000 jiwa ibu hamil dan 929 orang ibu menyusui yang menjadi korban dampak gempa dan mengalami masalah lkelancaran ASI(Arisjulyanto \& Hikmatushaliha, 2018; Astuti et al., 2015).

Dari uraian di atas peneliti tertarik meneliti pengaruh teknik marmet terhadap produksi ASI ibu pasca salin di Kecamatan Sikur Lombok Timur.

\section{METODE PENELITIAN}

Desain penelitian yang digunakan dalam penelitian ini adalah penelitian one group pretest postets design .Penelitian ini melakukan pengukuran jumlah produksi ASI ibu sebanyak dua kali yaitu sebelum dan sesudah diberikan terapi pijat marmet. jumlah sampel dalam penelitian ini sebanyak 17 responden yang diambil dengan teknik total sampling. Dan gtujuan penelitian ini adalah melihat pengaruh dari pijat marmet terhadap produksi ASI ibu menyusui di Kecamatan Sikur Kabupaten Lombok Timur.

\section{HASIL dan PEMBAHASAN}

\section{Karakteristik Responden}

Tabel 1. Karekteristik responden

\begin{tabular}{llc}
\hline Variabel & n & \% \\
\hline Pendidikan & & \\
Tidak Sekolah & 5 & 29,41 \\
SD & 5 & 29,41 \\
SMP & 3 & 11,76 \\
SMA & 4 & 23,52 \\
Pekerjaan & & \\
$\quad$ IRT & 17 & 100 \\
\hline
\end{tabular}

Berdasarkan data pada Tabel 1 menunjukan $29,41 \%$ responden tidak sekolah, 29,41\% tamat SD, $11,7 \%$ tamat SMP dan 23,52 tamat SMA. Sedangkan pekerjaan responden $100 \%$ hanya sebagai Ibu rumah tangga.

\begin{tabular}{lcccc}
\hline SIG & Mean & n & SD & P value \\
\hline Sebelum & 603,41 & 17 & 49,32 & 0,000 \\
Sesudah & 766,11 & 17 & 24,90 & \\
\hline
\end{tabular}

Berdasarkan hasil uji statistik, dapat diperoleh nilai rata-rata produksi ASI sebelum intervensi sebanyak 603,41 dan mengalami peningkatan setelah diberikan intervensi dengan pijat marmet menjadi 766,11. Nilai rata-rata Produksi ASI remaja menunjukan adanya peningkatan Produksi ASI setelah diberikan terapi pijat marmet sebesar 162,70 dengan $\mathrm{p}$ value 0,000 lebih kecil dari $\alpha=0,05$ artinya ada pengaruh yang signifikan pemberian terapi pijat marmet terhadap peningkatan produksi ASI ibu di Kecamatan Sikur Kabupaten Lombok Timur.

\section{PEMBAHASAN}

Berdasarkan hasil penelitian ini menunjukan. Peningkatan nilai rata-rata Produksi ASI remaja menunjukan adanya peningkatan Produksi ASI setelah diberikan terapi pijat marmet sebesar 162,70 dengan $\mathrm{p}$ value 0,000 lebih kecil dari $\alpha=0,05$ artinya ada pengaruh yang signifikan pemberian terapi pijat marmet terhadap peningkatan produksi ASI ibu di Kecamatan Sikur Kabupaten Lombok Timur.

Penelitian ini sejalan dengan penelitian Mardiyaningsih, Setyowati, \& Sabri (2011) dalam jurnalnya yang menyatakan metode kombinasi teknik marmet dan pijat okstosin efektif dapat meningkatkan produksi ASI ibu post seksio sesarea. Dan didukung oleh penelitian Ninggrum, et al., (2017) yang menyatakan Seluruh responden yang diberi teknik marmet mendapatkan produksi ASI yang cukup pada hari ke-7, dan menyatakan ada pengaruh pemberian pijat marmet terhadap peningkatan produksi ASI ibu menyusui.

Widiastuti, Arifah, \& Rachmawati (2015) menyatakan Pemberian perlakuan teknik marmet menyebabkan pengeluaran ASI lebih lancar. Responden lebih banyak yang merasakan aliran ASI lebih deras saat menyusui. Hasil pengamatan pada bayi dalam kelompok teknik marmet, bayi yang tenang dalam menyusu, tidak rewel saat menyusu dan tidur pulas setelah menyusu memiliki persentase lebih tinggi.

Hasil penelitian Desmawanti ( 2013)dijelaskan bahwa dengan memberikan masase pada areola mamae sejak dini sangat bermanfaat untuk membantu proses pengeluaran ASI. Pada postpartum yang diberikan intervensi 12 jam setelah bersalin, ASI keluar pada 18 jam setelah bersalin. Masase pada areola mamae merangsang pengeluaran oksitosin sehingga memperlancar proses pengeluaran ASI.

Teknik MARMET yaitu teknik cara memeras ASI secara manual dan mengutamakan let down 
reflex (LDR) atau reflek pengeluaran ASI. Teknik marmet merangsang LDR di awal proses memerah sehingga dapat menghasilkan ASI sebanyak 2-3 kali lipat dibanding tanpa menggunakan teknik LDR. Jika teknik ini dilakukan dengan efektif dan tepat, maka seharusnya tidak akan terjadi masalah dalam produksi ASI atau cara mengeluarkan ASI. (Astuti et al., 2015).

Teknik marmet mengeluarkan ASI secara manual dan membantu refleks pengeluaran susu (Milk Ejection Reflex) telah bekerja bagi ribuan ibu dengan cara yang tidak dimiliki sebelumnya. Bahkan ibu menyusui berpengalaman yang telah mampu mengeluarkan ASI diungkapkan akan menghasilkan lebih banyak susu dengan metode ini. Ibu yang sebelumnya telah mampu mengeluarkannya hanya sedikit, atau tidak sama sekali, mendapatkan hasil yang sangat baik (Ninggrum et al., 2017).

Teknik memerah ASI yang dianjurkan adalah dengan mempergunakan tangan dan jari karena praktis, efektif dan efisien dibandingkan dengan menggunakan pompa. Caranya memerah ASI menggunakan cara yang disebut dengan Teknik Marmet yang merupakan perpaduan antara teknik memerah dan memijat. Memerah dengan menggunakan tangan dan jari mempunyai keuntungan selain tekanan negatif dapat diatur, lebih praktis dan ekonomis karena cukup mencuci bersih tangan dan jari sebelum memeras ASI dengan Teknik marmet (Roesli \& Yohmi, 2009).

\section{Kesimpulan}

Berdasarkan hasil peneelitian dan uraian diatas dapat kita simpulkan bahwa ada pengaruh pemberian terapi pijat marmet terhadap tingkat produksi ASI ibu menyusui di Kecamatan Sikur Kabupaten Lombok Timur, dan pijat marmet merupakan solusi yang bisa dilakukan bagi ibu menyusui yang memiliki masalah produksi ASI selama menyusui.

\section{Daftar Pustaka}

Aldy, O. S., Lubis, B. M., Sianturi, P., Azlin, E., \& Tjipta, G. D. (2009). Dampak Proteksi Air Susu Ibu Terhadap Infeksi. Sari Pediatri, 11(3), 167173.

Andayani, D., Emilia, O., \& Ismail, D. (2017). Peran kelas ibu hamil terhadap pemberian ASI Eksklusif di Gunung Kidul. Berita Kedokteran Masyarakat, 33(7), 317-324.
Arisjulyanto, D., \& Hikmatushaliha, B. T. (2018). Home visiting dan layanan antar jemput ke rumah sakit lapangan untuk korban gempa: usulan dalam pengembangan rumah sakit lapangan. Berita Kedokteran Masyarakat, 34(11).

Astuti, S., Dewi, A., Judistiani, Rahmiati, L., \& Susanti, A. I. (2015). Asuhan Kebidanan NIFAS \&MENYUSUI. Jakarta: Erlangga.

Desmawanti. (2013). Penentu kecepatan pengeluaran air susu ibu setelah sectio caesarea. Jurnal Kesehatan Masyarakat Nasional, 7(8).

Dinkes NTB. (2019). Profil Kesehatan NTB 2018. Mataram.

Ervina, Yustina, I., \& Sudaryati, E. (2019). Nilai agama dan persepsi tentang praktik pemberian air susu ibu dua tahun: studi kualitatif di Aceh. Berita Kedokteran Masyarakat, 35(3), 83-90.

Evariny, A. (2008). Agar Asi Lancar di Awal Masa Menyusui.

Kadir, N. . (2014). Menelusuri akar masalah rendahnya presentase pemberian Asi eksklusif di Indonesia. Jurnal Al Hikmah, 15(1).

Mardiyaningsih, E., Setyowati, \& Sabri, L. (2011). Efektifitas Kombinasi Teknik Marmet Dan Pijat Oksitosin terhadap Produksi Asi Ibu Post Seksio di Rumah Sakit Wilayah Jawa Tengah. Jurnal Keperawatan Soedirman (The Soedirman Journal of Nursing), 6(1).

Ninggrum, A. D., Titisari, I., Kundarti, F. I., \& Setyarini, A. I. (2017). PENGARUH PEMBERIAN TEKNIK MARMET TERHADAP PRODUKSI ASI PADA IBU POST PARTUM DI BPM WILAYAH KERJA PUSKESMAS SUKORAME KOTA KEDIRI. Jurnal Ilmu Kesehatan Kesehatan, 5(2), 46-55.

Roesli, U., \& Yohmi, E. (2009). Manajemen laktasi. Jakarta: IDAI.

Soetjiningsih. (2012). Seri gizi klinik ASI Petunjuk Untuk Tenaga Kesehatan. Jakarta: EGC: EGC.

Widiastuti, A., Arifah, S., \& Rachmawati, W. R. (2015). Pengaruh Teknik Marmet terhadap Kelancaran Air Susu Ibu dan Kenaikan Berat Badan Bayi. Jurnal Kesehatan Masyarakat Nasional, 9(4), 315-319. 